\title{
PONTO DE VISTA DOS ACOMPANHANTES DE PUÉRPERAS ADOLESCENTES E SUA INFLUÊNCIA NO PROCESSO DO ALEITAMENTO MATERNO
}

\author{
Isabela Oliveira de Almeida*2, Luciane C. R. Fernandes ${ }^{2}$, Fernanda Garanhani de Castro Surita', Antonieta Keiko \\ Kakuda Shimo², Erika Zambrano Tanaka² \\ Faculdade de Ciências Médicas ${ }^{1}$; Faculdade de Enfermagem²/ UNICAMP
}

\section{Resumo}

A rede de apoio é fator importante na vida de puérperas adolescentes. Com o objetivo de conhecer a opinião e a influência do acompanhante da puérpera adolescente sobre a amamentação e os principais desafios vividos no processo do aleitamento, realizamos um estudo de abordagem qualitativa. Foram incluídos acompanhantes integrantes da rede de apoio de adolescentes puérperas participantes do ambulatório de Revisão Puerperal de adolescentes do Hospital da Mulher Prof Dr José Aristodemo Pinotti-UNICAMP, com tamanho amostral determinado por saturação de dados. Foram entrevistados oito acompanhantes. Foi possível formar três categorias: acompanhantes do gênero feminino, acompanhantes do gênero masculino e auxílio oferecido pelo acompanhante. A promoção do aleitamento materno exclusivo em puérperas adolescentes está diretamente ligada à sua rede de apoio, que pode atuar de modo positivo ou negativo.

Palavras-chave: Aleitamento materno; Adolescente; Apoio familiar de paciente.

\section{Introdução}

As puérperas se sentem apoiadas e seguras quando possuem uma rede de apoio. O estudo tem como objetivo conhecer a opinião e influência do acompanhante da puérpera adolescente sobre a amamentação e os principais desafios vividos no processo do aleitamento.

\section{Resultados e Discussão}

Estudo de abordagem qualitativa. Foram entrevistados acompanhantes integrantes da rede de apoio de adolescentes puérperas. Local: RPA/CAISM. Coleta de dados entre abril e maio de 2018. CAAE: 82739517.1.00005404. Questão norteadora: "Qual o seu papel no aleitamento materno?". Análise descrita por Minayo, técnica de saturação de dados.

Foram entrevistados 8 acompanhantes. O quadro a seguir mostra a caracterização da amostra.

Quadro 1 - Caracterização dos acompanhantes entrevistados

\begin{tabular}{|c|c|c|c|c|c|}
\hline E & IDADE & ESCOLARIDADE & GÊN. & PROFISSÃo & $\begin{array}{c}\text { GRAU DE } \\
\text { PARENTESCO }\end{array}$ \\
\hline E1 & 37 & EF incompleto & Fem. & Do lar & Mãe \\
\hline E2 & 23 & EF completo & Masc. & Açougueiro & Marido \\
\hline E3 & 21 & EM completo & Fem. & Do lar & Irmã \\
\hline E4 & 32 & EF completo & Fem. & Doméstica & Mãe \\
\hline E5 & 19 & EM incompleto & Fem. & Estudante & Cunhada \\
\hline E6 & 23 & EM completo & Masc. & Metalúrgico & Marido \\
\hline E7 & 53 & EM completo & Fem. & Mãe social & Mãe \\
\hline E8 & 28 & EF completo & Masc. & $\begin{array}{l}\text { Organizador } \\
\text { de eventos }\end{array}$ & Namorado \\
\hline
\end{tabular}

Categorias: 1) Rede de apoio primária: acompanhantes do gênero feminino; 2) Rede de apoio primária: acompanhantes do gênero masculino e 3) Auxílio oferecido pela rede de apoio primária. No geral, o estudo mostrou a rede de apoio de forma positiva. Os acompanhantes referem repassar informações e reforçar sobre a importância do aleitamento, porém nenhum relatou auxílio na prática.

"Ela tem dificuldade de gravar o horário das mamadas, então eu fico pegando no pé. (...) É um desafio, tem dificuldade, tem hora que não quer dar mais, aquele medo do peito ficar caído." (E7).

"Eu ajudava bastante, mas ela não tinha muito leite pra alimentar ele. Aí a médica passou, por isso ela não amamenta hoje." (E2)

"A minha família sempre leva legumes, verduras, e faz pra comer arroz integral, a gente ajuda ela na alimentação" (E3)

A promoção do aleitamento materno exclusivo em puérperas adolescentes está diretamente ligada à sua rede de apoio, buscando promover conforto e segurança à puérpera. Também é necessário o auxílio prático nos cuidados com o bebê e com a casa, para seu bem estar psicológico, emocional e físico.

\section{Conclusões}

O conhecimento da influência do acompanhante possibilita a enfermagem direcionar o cuidado para promover a amamentação e evitar o desmame precoce.

\section{Agradecimentos}

\section{Bolsa IC - PIBIC/UNICAMP CNPQ}

Tamara LB. Apoio recebido por mães adolescentes no processo de aleitamento materno. Rev. enferm. UFPE on line; 11(4): 1667-1675, abr.2017 